\title{
The Study of Selected Chemical Properties and Statistical Analysis of Tigris River Water Samples in Wasit Province/Iraq
}

\author{
Nadhum Shamkhi Rahal ${ }^{1}$ \\ Assistant professor /Technical Institut
}

Kut

\author{
Basima Abbas Jabir Al-humairi \\ Lecturer/Technical Institute of Kut
}

\section{$\underline{\text { Abstract }}$}

This research was conducted and aimed to study selected chemical properties of water samples taken from Tigris river in selected areas from the province of Wasit .The areas are regions of Suwiara and Numaniyah districts. Water chemical analyses were conducted and analyzed in the chemical laboratories of environment directorate in Wasit province. Data were statistically treated using Data fit software package. Simulations and models were built depending on the values of SAR, Ec, and $\mathrm{pH}$. The results showed an existence of high significant statistical relationships between $(\mathrm{SAR}, \mathrm{EC}$, and $\mathrm{pH}),(\mathrm{SAR}$ and $\mathrm{EC})$ and $(\mathrm{EC}$, and $\mathrm{pH})$ were found as represented in the high values of the coefficient of determination $\left(\mathrm{R}^{2}\right)$ for WQMsS2 and WQMsN2. Also, results showed that, the best statistical relationship was between (SAR and EC,) for both locations .

Keyword : Statistical analysis, SAR, EC, $\mathrm{pH}$, irrigation water quality,Tigris, WQMsS,WQMsN,coefficient of variation. 


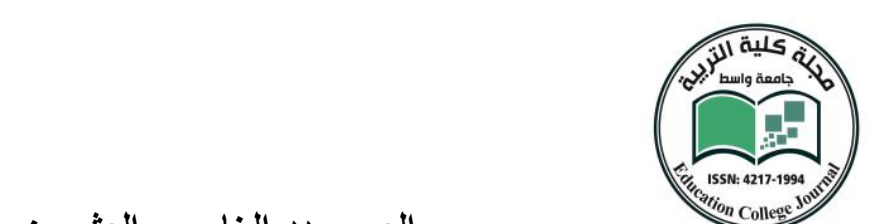

العـــــــد الخامس والعشرون

مجلــــة كليـــــة التربيــــة

دراسة الخصائص الكيميائية والتحليل الإحصائي لعينات لمياه نهر دجلة في محافظة واسط / العراق

$$
\text { المعهد التقبي / كوت عباس جابر }
$$

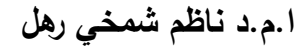

المعه التقتي / كوت

المستخلص)

اجري البحث بهذف دراسة الخصائص الكيميائية لعينات المياه لنهر دجلة لمناطق منتخبة من محافظة واسط

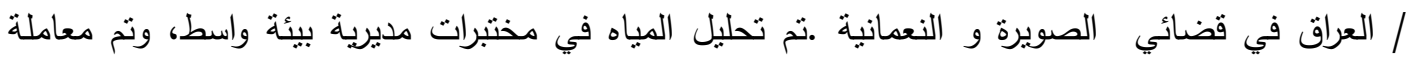
النتائج إحصائيا بالاعتماد على قيم SAR, EC ,PH لكل محطة فضلا عن إيجاد النموذج الرياضي ولئي المتحكم بالتتبؤ عن قيم أل SAR وال EC كمتغير معتمد وال EC ,pH , time كمتغيرات مستقلة .

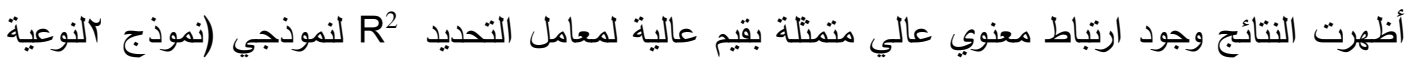

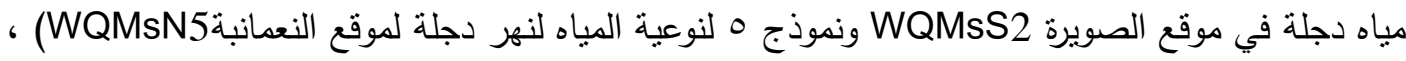
وتم بناء علاقة إحصائية مابين) و (SAR, EC ,p H) وبين (SAR, EC) وبين( النباين الإحصائي ان العلاقة الإحصائية بين (EAR و SAR ) هي أفضل علاقة لكلا الموقعين .

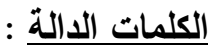

التحليل الإحصائي ، نسبة امتزاز الصوديوم، الايصالية الكهربائية ،درجة التفاعل ، نوعية الماء، نموذج

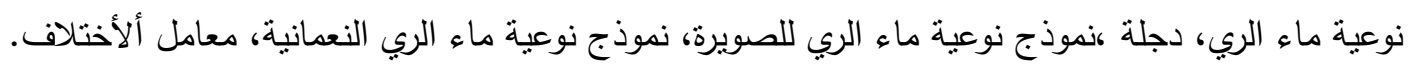




\section{1- Introduction}

Quality of Irrigation water is one of the main yield factors in the cultivation of agricultural and horticultural crops in the arid and semi-arid area, and, has turned into one of the major ecological concerns overall , and is affected by common and anthropogenic unsettling influences. For instance, waste water, overflow effluents, land recovery, air testimony and environmental change .Moreover, it is an essential requirement of human and industrial development in addition to being one of the most delicate parts of the environment,(Das and Acharya,2003 ; Sarala and Mageswari, 2014). It is becoming a global concern due to over increasing population and developmental activities that had over-exploited and polluted the water resources available, (Gubta, et al,2009). Parameters in charge for water quality variations are mainly related to domestic waste, industrial, runoff and agricultural (anthropogenic activities), (Ibrahim et al , 2015).

Rivers are vital fresh water systems of strategic importance across the world, providing main water resources for domestic, industrial, and form the lifeline of human society and playing a pivot role in assimilating or carrying industrial and Municipal wastewaters and runoff agricultural fields , (Basu and Lokesh,2013), and human activities have significantly affected its waters,( Radwan and AlSadek,2008).

Proper irrigation management is increasingly a demand and competition for high ,potable water grows. Also, accurate interpretation of water quality reports is essential for irrigation managers and this has resulted in increasing demand for monitoring river water quality . Also, it is crucial to understand what management changes are necessary for a long term and short term productivity, particularly for crops that are sensitive to changes in water quality. Moreover, it provides the primary assessment of the pollution status, (El-Sayed and Omran,2012;Basu and Lokesh,2013;Park, et al ,2014; Sharma, and Walia,2015).In addition, it is a critical factor, that influences human health and quantity and quality of grain production in the semi-humid and semi-arid area , (Hagras,2013).

The quality of irrigation water is governed by factors such as $\mathrm{pH}$, SAR, EC ,Na , $\mathrm{Mg}$, and its modelling is employed to predict, simulate and optimise the values of its qualitative parameters, and, it could be effective 
tools to simulate and predict pollutants transport in the water environment .Models are constructed and applied as valuable tools for quantitative analysis of the causeand-effect relation between management scenarios and water quality responses. And ,they widely used to support decision making of water management, (Wang et al ,2013; Sarala Thambavani and Uma Mageswari ,2014; Xuan Yi, et al , 2016). Moreover, the Disposal of ground water with high sodium concentrations has the potential to increase salinity and SAR of water in the river, and potentially reduce the quality of water for irrigation uses, (Cannon et al ,2004). And ,because of Tigris river is the main source of water for all life activities in the study area and, serves huge agricultural and residential area .And, due to the of lack information and little scientific studies of its water quality, it is necessary to evaluate the quality of its water in order to assess its suitability for various uses and to evolve suitable and strategic policies for the best uses of water resources in this area. Accordingly ,the objectives of this study were directed to evaluate and modelling selected chemical properties which are governing water quality in these areas.

\section{2-Materials and Methods}

\subsection{1-Study area :}

The work was conducted in two areas related to two districts from Wasit province, fig. (1) .The area is characterised mainly by large agricultural activities with minor industrial works .Tigris is the main source of water for the agricultural and domestic uses. Water samples were collected from Tigris river at both regions (Suwaira and Numaniyah), and chemically analysed for electrical conductivity( Ec),reaction( $\mathrm{pH})$, sodium $(\mathrm{Na})$, calcium $(\mathrm{Ca})$, and magnesium( $\mathrm{Mg})$ in chemical laboratories of Environmental directory of Wasit province according to methods documented in (Richards et al,1954). Sodium adsorption ratio ( SAR) was calculated according to method documented in (Richards et al,1954) as well.

\subsection{2-Data statistical processing :}

Data were statistically analysed for descriptive statistics(minimum, maximum, mean, range, mean standard error ,variance ,standard deviation ,coefficient variation, skewness, kurtosis, and correlation). Spss

statistical program version 20 was used for this purpose . Results are documented in tables 1 and 2. 


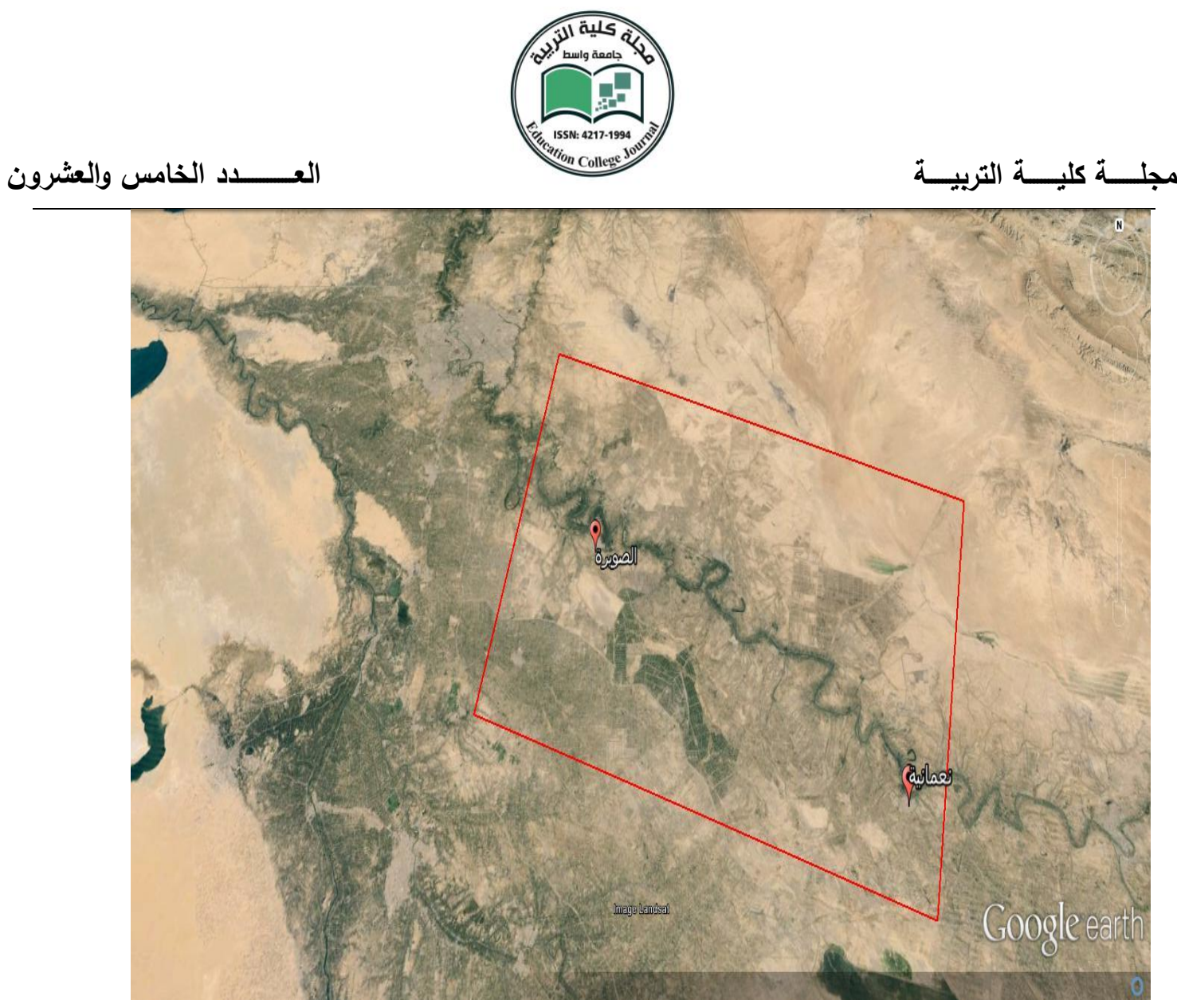

Fig.1 : location of study area and samling sites (Google earth )

\subsection{3-Construction of mathematical models :}

characterising the statistical relationship between (SAR, EC, $\mathrm{pH}$ and Time) ; between (SAR, Ecand Time ) and between (EC, pH and Time ). The results obtained from chemical tests table (1) for Suwaira and Numaniyah regions were used in statistical nonlinear estimation by using data fit software,9 (2014) to build a model for SAR depending on the variables (EC, Time). And to create the model for EC depending on the variables $(\mathrm{pH}$,Time). The maximum number of iterations used were (250) and the convergence criterion was (0.0000000001).Results were documented in tables $3,4,5,6,7$, and 8 . 


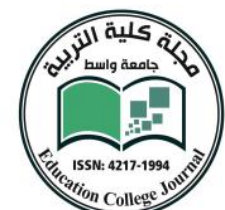

العـــــد الخامس والعشُون

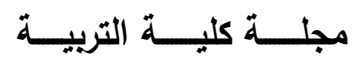

1.3- Results and discussion:

The quality of irrigation water is governed by factors as $(\mathrm{pH}, \mathrm{SAR}$,Ec , and concentration of ions like $\mathrm{Na}, \mathrm{Mg}, \mathrm{Ca}$, and potassium $(\mathrm{K})$, in addition to a time scale. The spatiotemporal variability of these factors affects the quality of irrigation water. Table (1) represents the values of a chemical parameter of Tigris water in Suwaira and Numaniyah regions and their descriptive statistics .

Table (1) chemical parameters and descriptive statistics for Suwaira and Numaniyah regions for the year 2014

\begin{tabular}{|c|c|c|c|c|c|c|c|c|c|c|c|c|}
\hline \multicolumn{7}{|c|}{ Suwaira Region } & \multicolumn{6}{|c|}{ Numaniyah Region } \\
\hline Time & $\begin{array}{l}\mathrm{Ca}^{+2} \\
\mathrm{ppm}\end{array}$ & $\begin{array}{c}\mathrm{Mg}^{+2} \\
\mathrm{ppm}\end{array}$ & $\begin{array}{l}\mathrm{Na}^{+1} \\
\mathrm{ppm}\end{array}$ & $\begin{array}{c}\text { EC } \\
\mu \text { S.cm }{ }^{-1}\end{array}$ & $\mathrm{pH}$ & SAR & $\mathrm{Ca}^{+2} \mathrm{ppm}$ & $\begin{array}{c}\mathrm{Mg}^{+2} \\
\mathrm{ppm}\end{array}$ & $\begin{array}{l}\mathrm{Na}^{+1} \\
\mathrm{ppm}\end{array}$ & $\begin{array}{c}\text { Ec } \\
\mu S . \mathrm{cm}^{-1}\end{array}$ & $\mathrm{pH}$ & SAR \\
\hline January & 88.500 & 35.500 & 93.000 & 1210.500 & 7.550 & 11.820 & 86.000 & 34.500 & 93.000 & 1189.000 & 7.450 & 11.980 \\
\hline February & 84.750 & 44.800 & 91.400 & 1220.000 & 7.700 & 11.360 & 85.000 & 44.000 & 86.400 & 1195.000 & 7.600 & 10.760 \\
\hline March & 82.500 & 34.900 & 95.500 & 1196.000 & 7.400 & 12.470 & 87.000 & 34.000 & 106.500 & 1257.000 & 7.350 & 13.700 \\
\hline April & 76.250 & 35.900 & 108.500 & 1198.000 & 7.635 & 14.490 & 79.700 & 39.000 & 103.450 & 1130.000 & 7.615 & 13.430 \\
\hline May & 73.750 & 30.400 & 86.050 & 1121.000 & 7.800 & 11.930 & 73.250 & 33.150 & 89.000 & 1187.500 & 7.700 & 12.200 \\
\hline June & 83.500 & 44.695 & 89.000 & 1450.500 & 7.720 & 11.120 & 84.350 & 47.000 & 88.600 & 1483.000 & 7.640 & 10.930 \\
\hline July & 84.050 & 41.200 & 99.500 & 1530.500 & 7.310 & 12.570 & 86.550 & 42.100 & 100.700 & 1534.000 & 7.460 & 12.560 \\
\hline August & 77.800 & 31.500 & 88.000 & 1403.500 & 7.365 & 11.910 & 82.650 & 31.500 & 92.900 & 1388.500 & 7.495 & 12.300 \\
\hline September & 73.000 & 30.150 & 86.050 & 1280.500 & 7.385 & 11.980 & 77.000 & 32.500 & 95.250 & 1358.500 & 7.435 & 12.870 \\
\hline October & 66.750 & 33.500 & 96.500 & 1226.000 & 7.700 & 13.630 & 68.650 & 32.700 & 99.500 & 1252.000 & 7.700 & 13.980 \\
\hline November & 80.100 & 35.500 & 76.750 & 1207.500 & 7.455 & 10.100 & 84.250 & 35.300 & 77.750 & 1195.000 & 7.515 & 10.060 \\
\hline December & 98.750 & 40.300 & 86.250 & 1250.000 & 7.480 & 10.340 & 105.000 & 41.500 & 97.000 & 1133.000 & 7.555 & 11.330 \\
\hline Min. & 66.570 & 30.150 & 76.750 & 1121.000 & 7.310 & 10.100 & 68.650 & 31.500 & 77.750 & 1130.000 & 7.350 & 10.060 \\
\hline Max. & 98.750 & 44.800 & 108.500 & 1530.500 & 7.800 & 14.490 & 105.000 & 47.000 & 106.500 & 1534.000 & 7.700 & 13.980 \\
\hline Range & 32.000 & 14.650 & 31.750 & 409.500 & 0.490 & 4.390 & 36.350 & 15.500 & 28.750 & 404.000 & 0.350 & 3.920 \\
\hline Mean & 80.808 & 36.528 & 91.375 & 1274.500 & 7.547 & 11.976 & 83.283 & 37.270 & 94.170 & 1292.041 & 7.542 & 12.175 \\
\hline
\end{tabular}




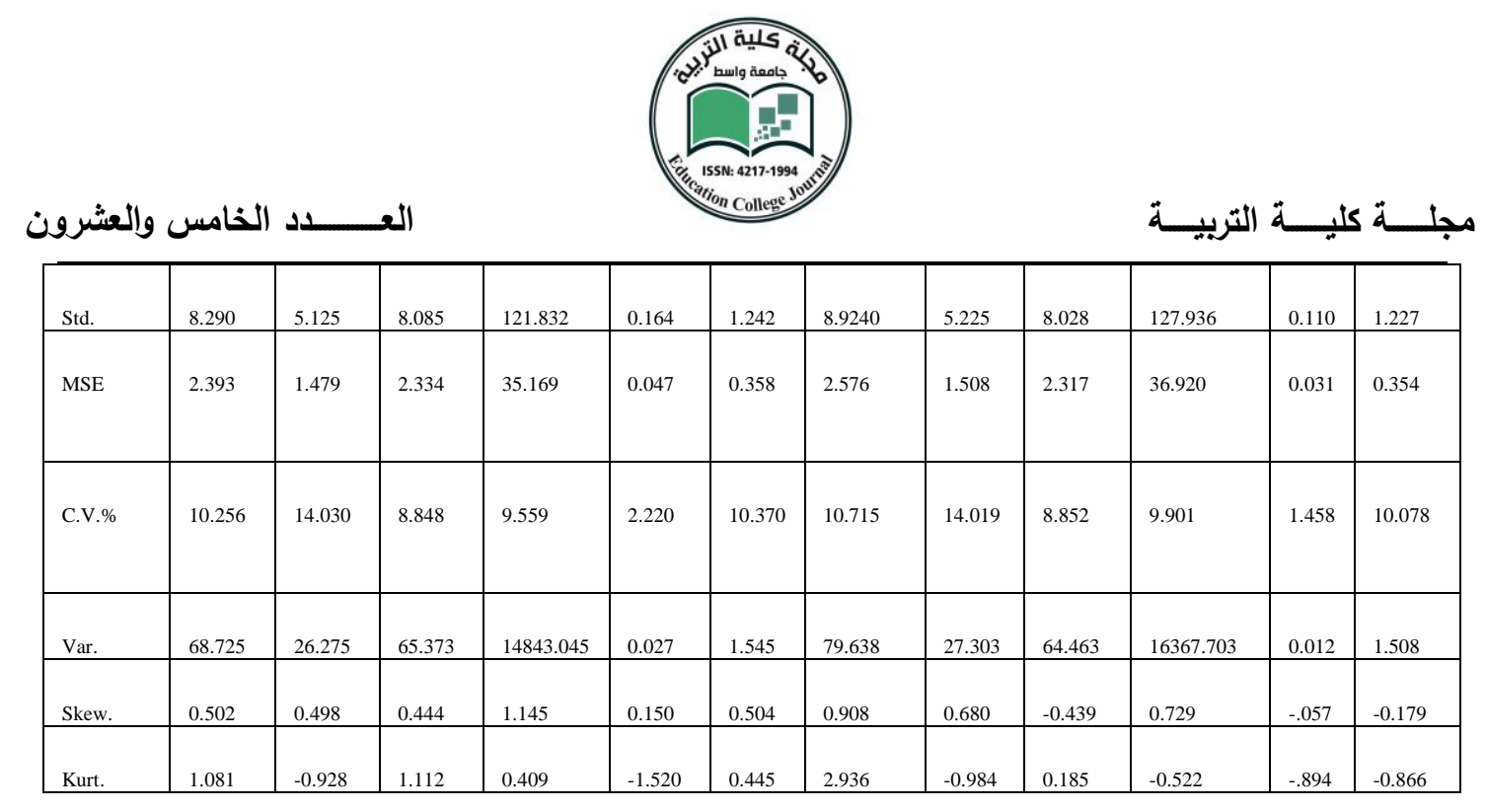

\subsection{1-Suwaira region:}

Descriptive statistics results presented in table (1) show that $\mathrm{Ca}^{+2}$ concentration ranged between $66.75 \mathrm{ppm}$ to $98.75 \mathrm{ppm}$ during October and December respectively .The coefficient of variation $(\mathrm{cv})$ of $\mathrm{Ca}$ ions was $(\mathrm{cv}=10.256 \%)$ and of mean squared error (MSE=2.393). $\mathrm{Mg}$ concentration ranged between $30.15 \mathrm{ppm}$ and $44.80 \mathrm{ppm}$ in September and February respectively, with a coefficient of variation $(14.030 \%)$ and MSE 1.479. Whereas Na concentration ranged from 76.75 to $108.50 \mathrm{ppm}$ in November and April respectively and was of less variability $(\mathrm{cv}=8.848 \%)$ and its MSE was (2.334).The electrical conductivity of water in this region ranged between $1121.00 \mu \mathrm{S} . \mathrm{cm}^{-1}$ and $1530.50 \mu \mathrm{S} . \mathrm{cm}^{-1}$ during May and July respectively and its coefficient of variation and MSE were 9.559\% and 35.169 respectively. Water reaction $(\mathrm{pH})$ was the least variable parameter $(\mathrm{cv}=2.220 \%)$. It's value ranged between 7.31 and 7.80 during July and May respectively and of MSE value 0.047. Sodium Adsorption Ratio (SAR) ranged between 10.10 and 14.49 in November and April respectively with MSE value (0.358). The pattern of variability of water quality parameters takes the form: $\mathrm{Mg}>\mathrm{SAR}>\mathrm{Ca}>\mathrm{Ec}>\mathrm{Na}>\mathrm{pH}$. The results show that the studied chemical parameters of water quality in this region was of low variability $(<15 \%)$. These variations may be inferred to the effects of anthropogenic influences and to the seasonal runoff ,(Basu and Lokesh , 2013 ; Sahoo, et al , 2016) and to the variations of the physical water qualities as turbidity, water temperature and water current velocity. 


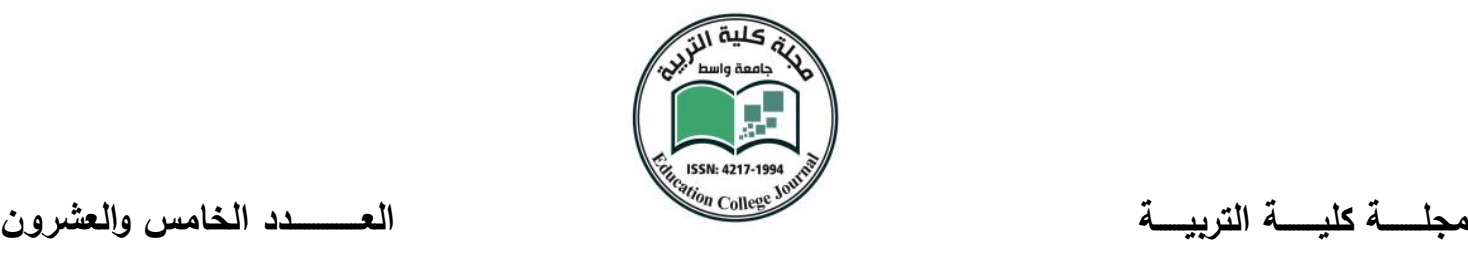

1.3.2 Numaniyah region:

Descriptive statistics presented in table (1) show that, Ca concentration ranged between $68.65 \mathrm{ppm}$ and 105.00ppm in October and December respectively ,the coefficient of variation of Calcium ions was $10.715 \%$ and its MSE is 2.576. Magnesium concentration was ranging from $31.5 \mathrm{ppm}$ and $47.00 \mathrm{ppm}$ for August and June respectively. The coefficient of variation of Magnesium concentration was $14.019 \%$ with MSE value 1.508. But, sodium concentration ranged from $77.75 \mathrm{ppm}$ to $106.05 \mathrm{ppm}$ during November and March months respectively, it s coefficient of variation and MSE were $(\mathrm{cv}=8.852 \%)$ and 2.317 respectively . The electrical conductivity of water in Numaniyah region ranged between 1130

$\mu \mathrm{S} . \mathrm{cm}^{-1}$ and $1534 \mu \mathrm{S} . \mathrm{cm}^{-1}$ during April and July respectively .The coefficient of variation and MSE of Ec was $9.901 \%$ and 36.932 respectively. Whereas, $\mathrm{pH}$ was the least variable parameter, and its values ranged between 7.35 and 7.70 during March and October respectively. The coefficient of variation of $\mathrm{pH}$ was $1.458 \%$ and the MSE was 0.031. Whoever, the minimum and maximum values of SAR in this region were 10.06 and 13.98 respectively in November and October respectively and the coefficient of variation of SAR was $10.078 \%$ with MSE 0.354.From the above mentioned results, we found that $\mathrm{pH}$ is the least variable parameter and Magnesium is the most variable parameter of water quality in this region. These variations may be due to the variation of the concentration these parameters in water,variation of physical environments such as temperature of water and the geologic nature of the origin which the soil derived from that water passed through and coming from, (Singh, et al, 2014; Radwan and El-Sadek,2008). In addition, this is may be due to the variability of these ions in untreated or partially treated wastewater disposed of in the river,(Sahoo, et al ,2016), and to the direct dumping of solid wastes and domestic sewage into the rivers, (Malla, et al, 2015). The pattern of the variation of these parameters having the form : $\mathrm{Mg}>\mathrm{Ca}>\mathrm{SAR}>\mathrm{Ec}>\mathrm{Na}>\mathrm{pH}$. Table(2) presents the correlation matrices between the studied parameters in both regions. The highest positive correlation was between SAR and Na ,their coefficients of correlation were 0.704 and 0.846 for Suwaira and Numaniyah regions respectively, they were both significant correlations $(\rho=0.95$ and 0.99$)$.And, the highest significant negative correlation coefficient was (-0.552) between SAR and $\mathrm{Ca}$ in Suwaira region, whereas in Numaniyah region was -0.531 between SAR and Mg. The lowest positive correlation was between SAR and EC(0.032) in Numaniyah region and between EC and $\mathrm{Na}(0.56)$ in Suwaira region. However, the lower 
negative correlation Was $(\mathrm{r}=-0.028$ and -0.133$)$ between $\mathrm{pH}$ and $\mathrm{Na}$, and $\mathrm{pH}$ and SAR respectively in Suwaira and Numaniyah regions respectively.

Table (2) Correlation metrics of the studied chemical properties for Tigris water

Suwaira Region
\begin{tabular}{|c|c|c|c|c|c|c|}
\hline & $\mathrm{Ca}^{+2}$ & $\mathrm{Mg}^{+2}$ & $\mathrm{Na}^{+1}$ & $\mathrm{Ec}$ & $\mathrm{pH}$ & SAR \\
\hline $\mathrm{Ca}^{+2}$ & 1.000 & & & & & \\
\hline $\mathrm{Mg}^{+2}$ & $0.725^{* *}$ & 1.000 & & & & \\
\hline $\mathrm{Na}^{+1}$ & 0.074 & 0.358 & 1.000 & & & \\
\hline $\mathrm{Ec}$ & 0.196 & 0.277 & 0.056 & 1.000 & & \\
\hline $\mathrm{pH}$ & -0.102 & 0.175 & -0.028 & -0.396 & 1.000 & \\
\hline SAR & $-0.552^{*}$ & -0.308 & $0.704^{* *}$ & -0.105 & -0.123 & 1.000 \\
\hline
\end{tabular}

Numaniyah Region

\begin{tabular}{|c|c|c|c|c|c|c|}
\hline & $\mathrm{Ca}^{+2}$ & $\mathrm{Mg}^{+2}$ & $\mathrm{Na}^{+1}$ & $\mathrm{Ec}$ & $\mathrm{pH}$ & SAR \\
\hline $\mathrm{Ca}^{+2}$ & 1.000 & & & & & \\
\hline $\mathrm{Mg}^{+2}$ & $0.545^{*}$ & 1.000 & & & & \\
\hline $\mathrm{Na}^{+1}$ & 0.175 & -0.168 & 1.000 & & & \\
\hline $\mathrm{Ec}$ & 0.308 & 0.091 & 0.081 & 1.000 & & \\
\hline $\mathrm{pH}$ & $-0.515^{*}$ & 0.214 & -0.291 & -0.316 & 1.000 & \\
\hline $\mathrm{SAR}$ & -0.308 & $-0.531^{*}$ & $0.846^{* *}$ & 0.032 & -0.133 & 1.000 \\
\hline
\end{tabular}

(Spearman -0ne tailed) *significant at $5 \%$, and ** significant at $1 \%$

\subsection{3 -Water quality Modelling(WQMs):}

Water quality assessment is vital phenomena for water management. And its modelling is very helpful to predict and simulate its fundamental parameters.

\subsubsection{1;Suwaira Region:}

Three nonlinear models were constructed ,two models for characterising the relation between SAR, $\mathrm{pH}, \mathrm{EC}$ and time . And the third one was to characterise the relation between $\mathrm{Ec}$,time and $\mathrm{pH}$,table (3),fig. $2 \mathrm{a}$ and $2 \mathrm{~b}$. The construction of these models depended on results derived from chemical tests and Datafit program. The results presented in table ( 4) show that the coefficients of determination $\left(\mathrm{R}^{2}\right)$ of water quality WQMs 


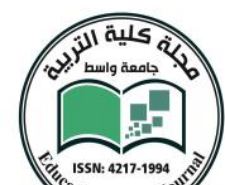

Table(3) models constructed to characterise the relation between Time, $\mathrm{pH}, \mathrm{Ec}$ , and SAR for Tigris water in Suwaira region

Model 1WQMsS1) : $\quad \mathrm{SAR}=\exp \left(\mathrm{a}_{0} * \mathrm{~T}+\mathrm{a}_{1} * \mathrm{EC}+\mathrm{a}_{2} * \mathrm{pH}+\mathrm{a}_{3}\right)$

Model 2(WQMsS2 : SAR $=\mathrm{a}_{0}+\mathrm{a}_{1} * \mathrm{~T}+\mathrm{a}_{2} * \mathrm{~T}^{2}+\mathrm{a}_{3} * \mathrm{~T}^{3}+\mathrm{a}_{4} * \mathrm{~T}^{4}+\mathrm{a}_{5} * \mathrm{~T}^{5}+\mathrm{a}_{6} / E C+\mathrm{a}_{7} / \mathrm{EC}^{2}+\mathrm{a}_{8} / \mathrm{EC}^{3}+\mathrm{a}_{9} / \mathrm{EC}^{4}+\mathrm{a}_{10} / \mathrm{EC}^{5}$

Model $3\left(\right.$ WQMsS3) : $\mathrm{EC}=\mathrm{a}_{0}+\mathrm{a}_{1} * \log (\mathrm{T})+\mathrm{a}_{2} * \log (\mathrm{T})^{2}+\mathrm{a}_{3} * \log (\mathrm{T})^{3}+\mathrm{a}_{4} * \log (\mathrm{T})^{4}+\mathrm{a}_{5} * \log (\mathrm{T})^{5}+\mathrm{a}_{6} * \mathrm{pH}+\mathrm{a}_{7} *(\mathrm{pH})^{2}+\mathrm{a}_{8} *(\mathrm{pH})^{3}+\mathrm{a}_{9} *(\mathrm{pH})^{4}+\mathrm{a}$

S1,WQMsS2andWQMs S3 are 0.095,0.986 and 0.995 respectively. And, the standard error of the estimates (E.S.E) of these models is $1.387,0.489$ and 28.248 respectively. Accordingly, we found that model 2 (WQMsS 2) is the

Table (4) coefficients of constructed models for Tigris water in Suwaira region

\begin{tabular}{|c|c|c|c|}
\hline coefficients & $\begin{array}{c}\text { Model } 1 \\
\text { (WQMsS1) }\end{array}$ & $\begin{array}{c}\text { Model2 } \\
\text { (WQMsS2) }\end{array}$ & $\begin{array}{c}\text { Model3 } \\
\text { (WQMsS3) }\end{array}$ \\
\hline$a_{0}$ & -0.0083 & -381699 & 14052484260.0 \\
\hline$a_{1}$ & 1.124 & 20.550 & 2561.2 \\
\hline$a_{2}$ & 0.029 & -12.382 & -9050.9 \\
\hline$a_{3}$ & 2.306 & 3.056 & 9969.4 \\
\hline$a_{4}$ & - & -0.306 & -4402.8 \\
\hline$a_{5}$ & - & 0.011 & 679.6 \\
\hline$a_{6}$ & - & $2.449 \mathrm{E}+09$ & -9380178853.0 \\
\hline$a_{7}$ & - & $-6.26 \mathrm{E}+12$ & 2504201671.0 \\
\hline$a_{8}$ & - & $7.95 \mathrm{E}+15$ & -334223285.1 \\
\hline$a_{9}$ & - & $-5.03 \mathrm{E}+18$ & 22300389.4 \\
\hline$a_{10}$ & - & $1.27 \mathrm{E}+21$ & -595094.1 \\
\hline Square Regression $R^{2}$ & 0.095 & 0.986 & 0.995 \\
\hline $\begin{array}{c}\text { Standard Error of the } \\
\text { Estimate(S.E) }\end{array}$ & 1.387 & 0.489 & 28.248 \\
\hline
\end{tabular}




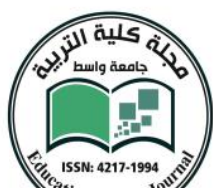

العـــــــد الخامس والعشرون

مجلـــة كليــــة التربيــــة

best model for simulation values of SAR for Tigris water in Suwaira region .This is can be confirmed from the results presented in table (5). The residuals(negatives) in model WQMs S1 ranged from -0.28 to -1.36 in May and November respectively with error ranged from $-2.31 \%$ and $-13.50 \%$ in May and November respectively , and its positive residuals ranged between 0.13 and 2.23 in August and April respectively with error ranged between $1.12 \%$ and $15.41 \%$ in August and April respectively. Whereas, the residuals(negatives) in model WQMsS2 ranged between -0.02 and -0.34 in December and March with error ranged between -0.01 and -2.71 in October and March respectively, and its positive residuals ranged between 0.00 to 0.21 in October and April respectively with error ranged

Table (5) measured and estimated SAR and Ec values from chemical test and Data fit software program for Suwaira region.

\begin{tabular}{|c|c|c|c|c|c|c|c|c|c|c|c|c|}
\hline \multirow[t]{2}{*}{ Time } & \multicolumn{4}{|c|}{ Model 1 (WQMsS1) } & \multicolumn{4}{|c|}{ Model 2 (WQMsS2) } & \multicolumn{4}{|c|}{ Model 3 (WQMsS3) } \\
\hline & $\begin{array}{c}\text { SAR } \\
\text { from } \\
\text { chemic } \\
\text { al test }\end{array}$ & $\begin{array}{c}\text { SAR } \\
\text { from } \\
\text { data } \\
\text { fit }\end{array}$ & $\begin{array}{c}\text { Residual } \\
\mathrm{s}\end{array}$ & $\begin{array}{c}\text { Error } \\
\%\end{array}$ & $\begin{array}{c}\text { SAR } \\
\text { from } \\
\text { chemic } \\
\text { al } \\
\text { analysis }\end{array}$ & $\begin{array}{c}\text { SAR } \\
\text { from } \\
\text { data } \\
\text { fit }\end{array}$ & $\begin{array}{c}\text { Residual } \\
\mathrm{s}\end{array}$ & $\begin{array}{c}\text { Error } \\
\%\end{array}$ & $\begin{array}{c}\mathrm{EC} \\
\text { from } \\
\text { chemic } \\
\text { al test } \\
\mu \mathrm{S} . \mathrm{cm}^{-1}\end{array}$ & $\begin{array}{c}\text { EC } \\
\text { from } \\
\text { data fit } \\
\mu \mathrm{S} . c \\
\mathrm{~m}^{-1}\end{array}$ & $\begin{array}{c}\text { Residua } \\
\text { ls }\end{array}$ & $\begin{array}{c}\text { Error } \\
\%\end{array}$ \\
\hline January & 11.82 & $\begin{array}{c}12.5 \\
3\end{array}$ & -0.71 & -6.04 & 11.82 & $\begin{array}{c}11.8 \\
7\end{array}$ & -0.05 & -0.42 & 1210.5 & $\begin{array}{c}1210.4 \\
9\end{array}$ & 0.01 & 0.001 \\
\hline February & 11.36 & $\begin{array}{c}12.4 \\
9\end{array}$ & -1.13 & -9.98 & 11.36 & $\begin{array}{c}11.1 \\
5\end{array}$ & 0.21 & 1.88 & 1220 & $\begin{array}{c}1220.2 \\
7\end{array}$ & -0.27 & -0.023 \\
\hline March & 12.47 & $\begin{array}{c}12.2 \\
6\end{array}$ & 0.21 & 1.66 & 12.47 & $\begin{array}{c}12.8 \\
1\end{array}$ & -0.34 & -2.71 & 1196 & $\begin{array}{c}1194.8 \\
7\end{array}$ & 1.13 & 0.094 \\
\hline April & 14.49 & $\begin{array}{c}12.2 \\
6\end{array}$ & 2.23 & 15.41 & 14.49 & $\begin{array}{c}14.2 \\
8\end{array}$ & 0.21 & 1.45 & 1198 & $\begin{array}{c}1199.2 \\
2\end{array}$ & -1.22 & -0.102 \\
\hline May & 11.93 & $\begin{array}{c}12.2 \\
1\end{array}$ & -0.28 & -2.31 & 11.93 & $\begin{array}{c}11.9 \\
2\end{array}$ & 0.01 & 0.05 & 1121 & $\begin{array}{c}1121.0 \\
1\end{array}$ & -0.01 & -0.001 \\
\hline June & 11.12 & $\begin{array}{c}12.1 \\
4\end{array}$ & -1.02 & -9.16 & 11.12 & $\begin{array}{c}11.2 \\
0\end{array}$ & -0.08 & -0.70 & 1450.5 & $\begin{array}{c}1451.7 \\
2\end{array}$ & -1.22 & -0.084 \\
\hline
\end{tabular}




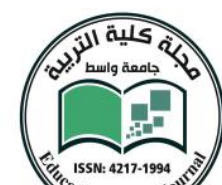

\begin{tabular}{|c|c|c|c|c|c|c|c|c|c|c|c|c|}
\hline July & 12.57 & $\begin{array}{c}11.8 \\
8\end{array}$ & 0.69 & 5.46 & 12.57 & $\begin{array}{c}12.5 \\
6\end{array}$ & 0.01 & 0.09 & 1530.5 & $\begin{array}{c}1532.0 \\
1\end{array}$ & -1.51 & -0.099 \\
\hline August & 11.91 & $\begin{array}{c}11.7 \\
8\end{array}$ & 0.13 & 1.12 & 11.91 & $\begin{array}{c}11.8 \\
1\end{array}$ & 0.10 & 0.86 & 1403.5 & $\begin{array}{c}1387.1 \\
2\end{array}$ & 16.38 & 1.167 \\
\hline $\begin{array}{c}\text { Septemb } \\
\text { er }\end{array}$ & 11.98 & $\begin{array}{c}11.6 \\
6\end{array}$ & 0.32 & 2.71 & 11.98 & $\begin{array}{c}12.0 \\
9\end{array}$ & -0.11 & -0.92 & 1280.5 & $\begin{array}{c}1301.1 \\
3\end{array}$ & -20.63 & -1.611 \\
\hline October & 13.63 & $\begin{array}{c}11.6 \\
7\end{array}$ & 1.96 & 14.37 & 13.63 & $\begin{array}{c}13.6 \\
3\end{array}$ & 0.00 & -0.01 & 1226 & $\begin{array}{c}1223.6 \\
4\end{array}$ & 2.36 & 0.193 \\
\hline $\begin{array}{c}\text { Novemb } \\
\text { er }\end{array}$ & 10.1 & $\begin{array}{c}11.4 \\
6\end{array}$ & -1.36 & -13.50 & 10.10 & $\begin{array}{c}10.0 \\
5\end{array}$ & 0.05 & 0.49 & 1207.5 & $\begin{array}{c}1198.7 \\
0\end{array}$ & 8.80 & 0.728 \\
\hline $\begin{array}{c}\text { Decembe } \\
\mathrm{r}\end{array}$ & 10.34 & $\begin{array}{c}11.3 \\
8\end{array}$ & -1.04 & -10.05 & 10.34 & $\begin{array}{c}10.3 \\
6\end{array}$ & -0.02 & -0.18 & 1250 & $\begin{array}{c}1253.8 \\
1\end{array}$ & -3.81 & -0.305 \\
\hline
\end{tabular}

between $-0.01 \%$ and $1.88 \%$ in October and February respectively. And in Model WQMsS3 the residuals (negatives) ranged between -0.01 to -20.63 in May and September respectively, with error ranged between -0.001 and -1.611 in May and September respectively. And its positive residuals were ranging from 0.01 to 16.38 in January and August respectively with error ranged between $0.001 \%$ to $1.167 \%$ in January and August respectively. This means that there are some parameters were not included in the construction of modelsWQMsS1 and WQMsS3, which caused these large values of residuals and errors in models WQMsS1 and WQMsS3.

\subsubsection{2 -Numaniyah Region(WQMsN):}

Three models were constructed to characterise the water quality of SAR of water.Two models(WQMsN4 and N5) for characterising the relation between $\mathrm{SAR}, \mathrm{pH}, \mathrm{EC}$, and time. And the third (WQMsN 6) was to characterise the relation between Ec ,time and $\mathrm{pH}$,table (6),fig. 3a and 3b. Table( 7) presents the coefficients 
of the constructed water quality models,WQMsN4, WQMsN5, and WQMsN6. The coefficients of Determinations

$\left(\mathrm{R}^{2}\right)$ of these Models are $0.0269,0.99$ and 0.998 for WQMsN 4 ,WQMsN 5 and WQMsN6 respectively with a standard error of estimates (ESE) 1.419,

Table (6) models constructed to characterize the relation between Time ,pH, Ec , and SAR for Tigris water in Numaniyah region

Model $4\left(\right.$ WQMsN4) : $\quad \mathrm{SAR}=\exp \left(\mathrm{a}_{0} * \mathrm{~T}+\mathrm{a}_{1} * \mathrm{EC}+\mathrm{a}_{2} * \mathrm{pH}+\mathrm{a}_{3}\right)$

Model 5(WQMsN5) :

$\mathrm{SAR}=\mathrm{a}_{0}+\mathrm{a}_{1} * \mathrm{~T}+\mathrm{a}_{2} * \mathrm{~T}^{2}+\mathrm{a}_{3} * \mathrm{~T}^{3}+\mathrm{a}_{4} * \mathrm{~T}^{4}+\mathrm{a}_{5} * \mathrm{~T}^{5}+\mathrm{a}_{6} * \ln \left(E C^{2}\right)+\mathrm{a}_{7} * \ln (\mathrm{EC})^{2}+\mathrm{a}_{8} * \ln (\mathrm{EC})^{3}+\mathrm{a}_{9} * \ln (\mathrm{EC})^{4}+\mathrm{a}_{10} * \ln (\mathrm{EC})^{5}$

Model 6(WQMsN6) :

$\mathrm{EC}=\mathrm{a}_{0}+\mathrm{a}_{1} / \mathrm{T}+\mathrm{a}_{2} * \mathrm{pH}+\mathrm{a}_{3} / \mathrm{T}^{2}+\mathrm{a}_{4} * \mathrm{pH}^{2}+\mathrm{a}_{5} * \mathrm{pH} / \mathrm{T}+\mathrm{a}_{6} / \mathrm{T}^{3}+\mathrm{a}_{7} * \mathrm{pH}^{3}+\mathrm{a}_{8} * \mathrm{pH}^{2} / \mathrm{T}+\mathrm{a}_{9} * \mathrm{pH} / \mathrm{T}^{2}$

2.096 and 33.145 respectively. As a result, we can notice that the modelWQMsN5 is the best among constructed WQMs. This is because of it's high $\left(\mathrm{R}^{2}\right)$ value $(0.99)$ and low ESE value (2.096) comparing to values of WQMsN4 and WQMSN6. Results listed in table (8)confirm these findings. Table 8 presents the SAR and EC measured and estimated from chemical tests and Data fit software .Residuals (negatives ) of the WQMsN4 range between -0.54 and -2.04 in January and November respectively with error ranged between $-4.49 \%$ and $-20.27 \%$ in January and November respectively. However,its positive residuals ranged between 0.13 to 2.1 during May and October respectively with error ranged between $1.10 \%$ and $15.02 \%$ in May and October respectively. Whereas, for WQMsN5, the residuals(negatives) ranged from -0.001 to -0.013 in January; July and August respectively, with error ranged between - $0.007 \%-0.108 \%$ in January and August respectively and its positive residuals ranged between 0.000 and 0.012 in April and September respectively with error $0.011 \%$ and $0.095 \%$ during October and September respectively. However in WQMsN6 negative residuals ranged from 0.951 to -20.103 with error ranged between $-0.076 \%$ and $-1.682 \%$ in March and November respectively. And, the positive residuals of the WQMsN6 ranged from 


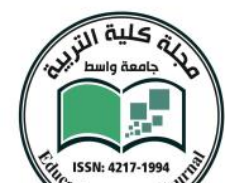

العـــــــد الخامس والعشرون

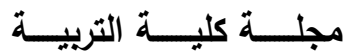

0.082 to 27.029 in October and December respectively with error ranged from $0.007 \%$ to $2.025 \%$ in October and December respectively. Accordingly, the WQMsN5 is the best model for characterising the relation between SAR,

Ec and Time and gives reasonable and acceptable values for SAR of irrigation water in Numaniyah region and very close to results obtained from chemical test. This is due to the low values of its residuals and error percentage comparing to that of WQMsN4 and WQMsN6 models.

Table (7) coefficients of models constructed to characterise the relation betweenTime, $\mathrm{pH}, \mathrm{Ec}$, and SAR for Tigris water in Numaniyah region

\begin{tabular}{|c|c|c|c|}
\hline Coefficients & Model 4 (WQMsN4) & Model 5(WQMsN5) & Model 6( WQMsN6) \\
\hline$a_{0}$ & $-2.75 E-03$ & $2.76 \mathrm{E}+09$ & 66305798.2 \\
\hline$a_{1}$ & $-3.25 \mathrm{E}-05$ & -5.52899 & 9533742.1 \\
\hline$a_{2}$ & -0.10254 & 1.72451 & -26514527.8 \\
\hline$\overline{a_{3}}$ & 3.332477 & -0.18085 & -2280631.8 \\
\hline$a_{4}$ & & $5.26 \mathrm{E}-03$ & 3532598.1 \\
\hline$a_{5}$ & - & $6.01 \mathrm{E}-05$ & -2409347.4 \\
\hline$a_{6}$ & - & $-1.9 \mathrm{E}+09$ & 94524.6 \\
\hline$a_{7}$ & - & $5.31 \mathrm{E}+08$ & -156814.3 \\
\hline$a_{8}$ & - & $-7.4 \mathrm{E}+07$ & 152257.8 \\
\hline$a_{9}$ & - & 5107140 & 289074.7 \\
\hline$a_{10}$ & - & -141587 & - \\
\hline $\begin{array}{c}\text { Square Regressions } \\
R^{2}\end{array}$ & 0.0269 & 0.99 & 0.998 \\
\hline $\begin{array}{l}\text { Standard Error of } \\
\text { the Estimate(S.E) }\end{array}$ & 1.419 & 2.096 & 33.145 \\
\hline
\end{tabular}




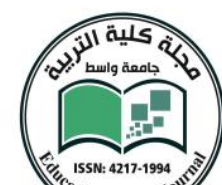

العـــــــد الخامس والعشرون

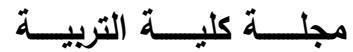

Table (8) measured and estimated SAR and Ec values from chemical test and Data fit software program for Numaniyah Region

\begin{tabular}{|c|c|c|c|c|c|c|c|c|c|c|c|c|}
\hline \multirow[t]{2}{*}{ Time } & \multicolumn{4}{|c|}{ Model 4 (WQMsN4) } & \multicolumn{4}{|c|}{ Model 5(WQMsN5) } & \multicolumn{4}{|c|}{ Model 6 (WQMsN6) } \\
\hline & $\begin{array}{c}\text { SAR } \\
\text { from } \\
\text { chemic } \\
\text { al test }\end{array}$ & $\begin{array}{c}\text { SAR } \\
\text { from } \\
\text { data } \\
\text { fit }\end{array}$ & $\begin{array}{c}\text { Residual } \\
\mathrm{s}\end{array}$ & $\begin{array}{c}\text { Error } \\
\%\end{array}$ & $\begin{array}{c}\text { SAR } \\
\text { from } \\
\text { chemic } \\
\text { al } \\
\text { analysis }\end{array}$ & $\begin{array}{c}\text { SAR } \\
\text { from } \\
\text { data } \\
\text { fit }\end{array}$ & $\begin{array}{l}\text { Residual } \\
\mathrm{s}\end{array}$ & $\begin{array}{c}\text { Error } \\
\%\end{array}$ & $\begin{array}{c}\mathrm{EC} \\
\text { from } \\
\text { chemic } \\
\text { al test } \\
\mu \mathrm{S} . \mathrm{cm}^{-} \\
1\end{array}$ & $\begin{array}{c}\mathrm{EC} \\
\text { from } \\
\text { data fit } \\
\mu \mathrm{S} . \mathrm{c} \\
\mathrm{m}^{-1}\end{array}$ & $\begin{array}{c}\text { Residual } \\
\text { s }\end{array}$ & $\begin{array}{c}\text { Error } \\
\%\end{array}$ \\
\hline January & 11.98 & $\begin{array}{c}12.5 \\
2\end{array}$ & -0.54 & -4.49 & $\begin{array}{c}11.9 \\
8\end{array}$ & $\begin{array}{c}11.9 \\
8\end{array}$ & -0.001 & -0.007 & 1189 & 1188.9 & 0.109 & 0.009 \\
\hline February & 10.76 & $\begin{array}{c}12.2 \\
9\end{array}$ & -1.53 & -14.25 & $\begin{array}{c}10.7 \\
6\end{array}$ & $\begin{array}{c}10.7 \\
5\end{array}$ & 0.004 & 0.039 & 1195 & 13.5 & -1.597 & $\begin{array}{c}-- \\
13.36 \\
0\end{array}$ \\
\hline March & 13.70 & $\begin{array}{c}12.5 \\
5\end{array}$ & 1.14 & 8.34 & $\begin{array}{c}13.7 \\
0\end{array}$ & $\begin{array}{c}13.7 \\
0\end{array}$ & -0.006 & -0.042 & 1257 & 1258.0 & -0.951 & -0.076 \\
\hline April & 13.43 & $\begin{array}{c}12.2 \\
3\end{array}$ & 1.20 & 8.92 & $\begin{array}{c}13.4 \\
3\end{array}$ & $\begin{array}{c}13.4 \\
3\end{array}$ & 0.000 & -0.003 & 1130 & 1119.4 & 10.553 & 0.934 \\
\hline May & 12.20 & $\begin{array}{c}12.0 \\
7\end{array}$ & 0.13 & 1.10 & $\begin{array}{c}12.2 \\
0\end{array}$ & $\begin{array}{c}12.2 \\
0\end{array}$ & 0.004 & 0.032 & 1187.5 & 1184.2 & 3.289 & 0.277 \\
\hline June & 10.93 & $\begin{array}{c}11.9 \\
9\end{array}$ & -1.06 & -9.71 & $\begin{array}{c}10.9 \\
3\end{array}$ & $\begin{array}{c}10.9 \\
3\end{array}$ & 0.003 & 0.030 & 1483 & 1500.5 & -17.460 & -1.177 \\
\hline July & 12.56 & $\begin{array}{c}12.1 \\
6\end{array}$ & 0.39 & 3.13 & $\begin{array}{c}12.5 \\
6\end{array}$ & $\begin{array}{c}12.5 \\
6\end{array}$ & -0.001 & -0.008 & 1534 & 1516.8 & 17.228 & 1.123 \\
\hline August & 12.30 & $\begin{array}{c}12.1 \\
4\end{array}$ & 0.15 & 1.25 & $\begin{array}{c}12.3 \\
0\end{array}$ & $\begin{array}{c}12.3 \\
1\end{array}$ & -0.013 & -0.108 & 1388.5 & 1406.8 & --18.310 & -1.319 \\
\hline $\begin{array}{c}\text { Septemb } \\
\text { er }\end{array}$ & 12.87 & $\begin{array}{c}12.2 \\
0\end{array}$ & 0.68 & 5.25 & $\begin{array}{c}12.8 \\
7\end{array}$ & $\begin{array}{c}12.8 \\
6\end{array}$ & 0.012 & 0.095 & 1358.5 & 1358.4 & 0.129 & 0.010 \\
\hline October & 13.98 & $\begin{array}{c}11.8 \\
8\end{array}$ & 2.10 & 15.02 & $\begin{array}{c}13.9 \\
8\end{array}$ & $\begin{array}{c}13.9 \\
8\end{array}$ & 0.002 & 0.011 & 1252 & 1251.9 & 0.082 & 0.007 \\
\hline Novemb & 10.06 & 12.1 & -2.04 & -20.27 & 10.0 & 10.0 & -0.005 & -0.054 & 1195 & 1215.1 & -20.103 & -1.682 \\
\hline
\end{tabular}




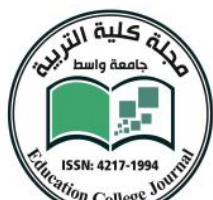

العــــــــد الخامس والعشرون

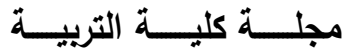

\begin{tabular}{|c|c|c|c|c|c|c|c|c|c|c|c|c|}
\hline er & & 0 & & & 6 & 6 & & & & & & \\
\hline $\begin{array}{c}\text { Decembe } \\
\mathrm{r}\end{array}$ & 11.33 & $\begin{array}{c}11.9 \\
6\end{array}$ & -0.62 & -5.51 & $\begin{array}{c}11.3 \\
3\end{array}$ & $\begin{array}{c}11.3 \\
3\end{array}$ & 0.002 & 0.015 & 1335 & 1308.0 & 27.029 & 2.025 \\
\hline
\end{tabular}

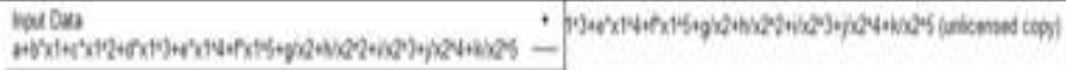

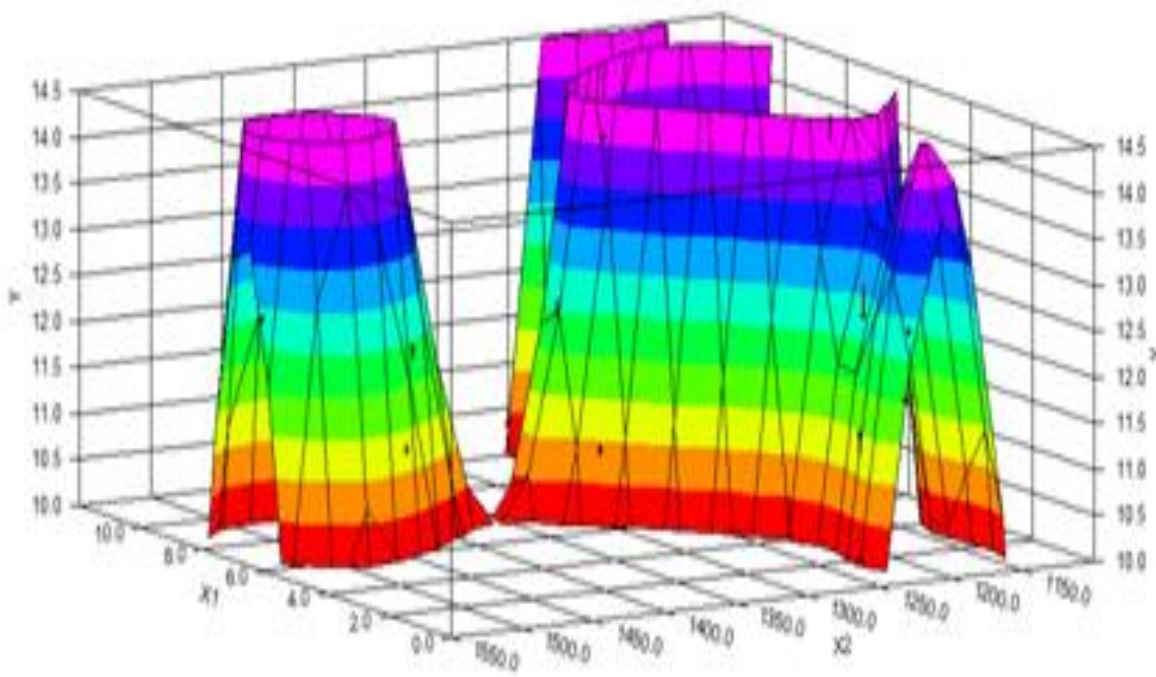

Fig(2 a) plot of model WQMsS3 [y axis represents SAR , $\mathrm{X}_{1}$ represents Time and $\mathrm{X}_{2}$ for Ec] 

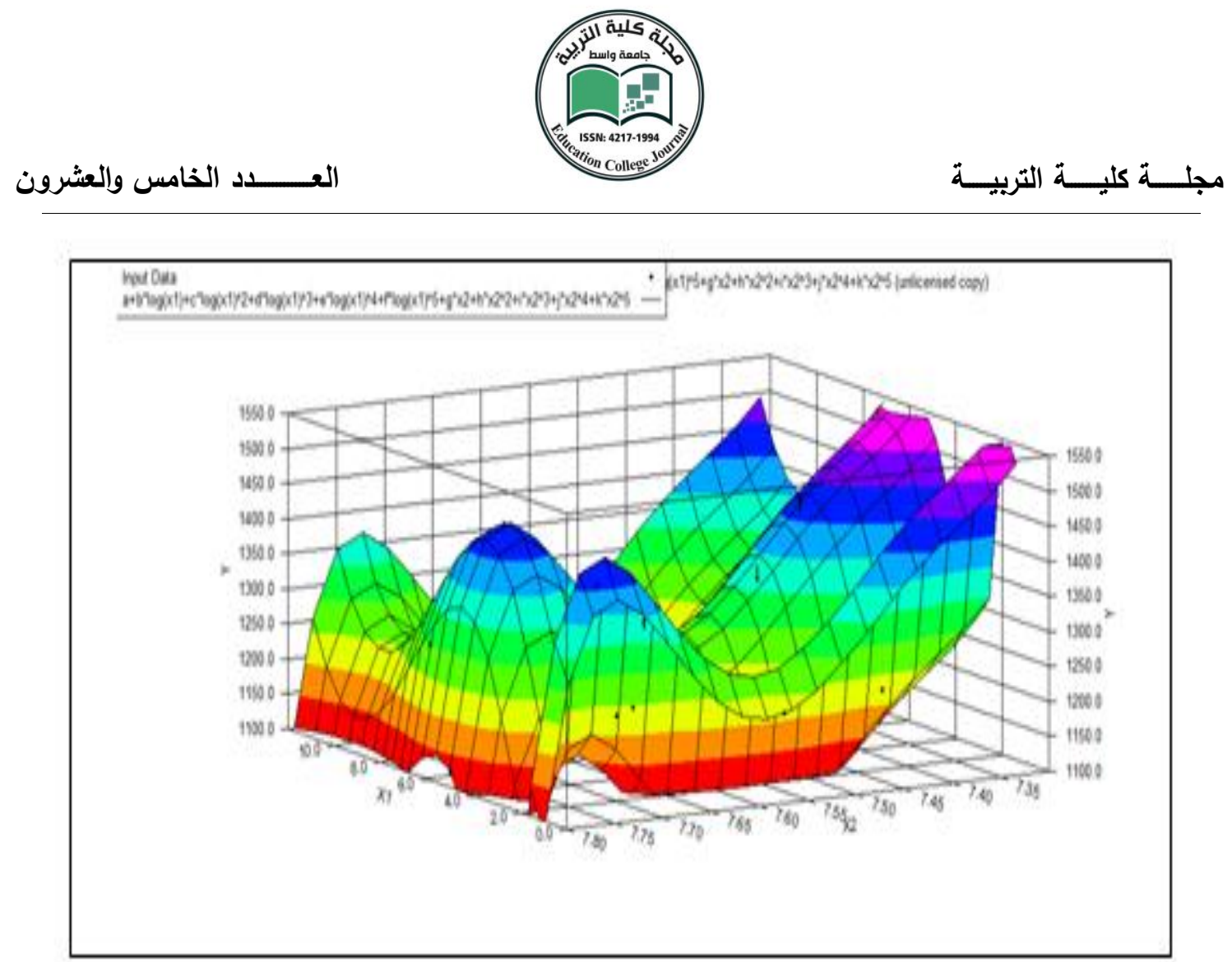

Fig ( 2 b ) plot of model WQMsS3 [ y axis represents Ec , $\mathrm{X}_{1}$ for Time and $\mathrm{X}_{2}$ for $\mathrm{pH}$ ] 


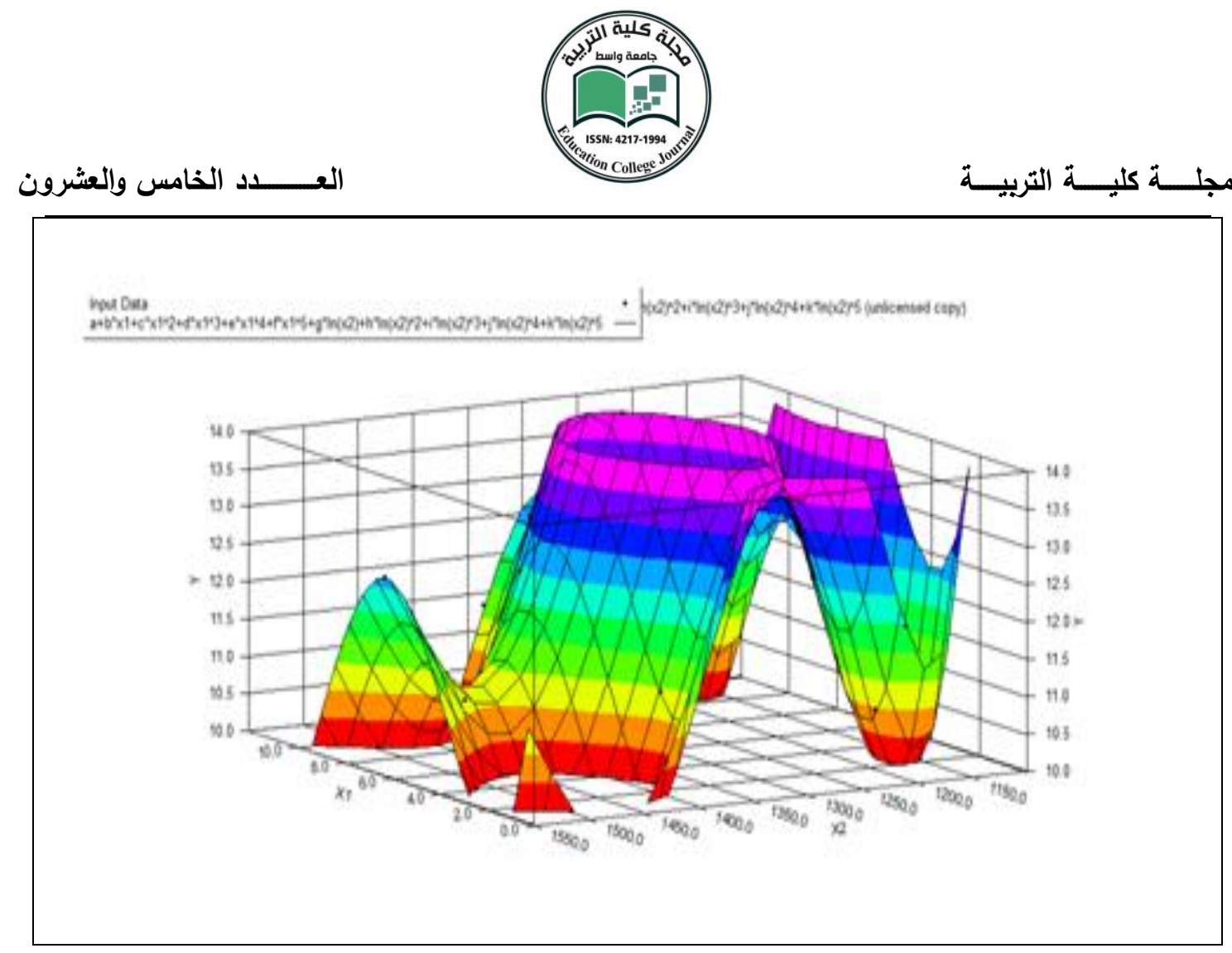

Fig.(3 a) :plot of WQMsN5:[Y represents $S A R, X_{1}$ represents Time and $X_{2}$ for Ec] 


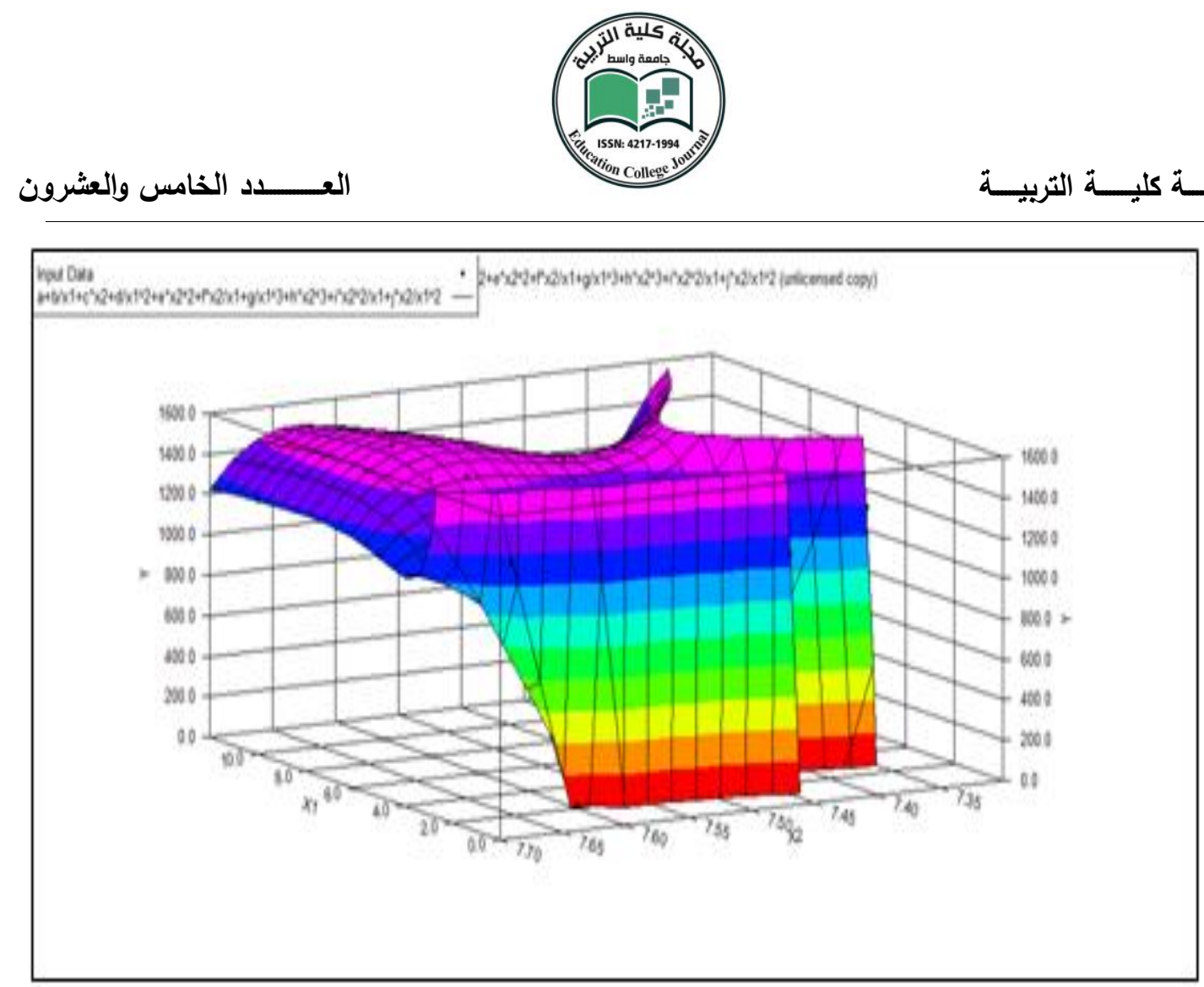

Fig.(3b )plot of WQMsN6, [Y represents EC , $\mathrm{X}_{1}$ represents time and $\mathrm{X}_{2}$ for $\left.\mathrm{pH}\right]$

\section{4-Conclusions and Recommendations:-}

Quality of irrigation water is governed by factors such as $\mathrm{pH}, \mathrm{Ec}, \mathrm{Na}, \mathrm{Mg}, \mathrm{Ca}$, $\mathrm{K}, \mathrm{SAR}$...etc., and it can be used to assess the risks of soil properties related to plant growth and soil uses for engineering purposes for instance, infiltration rate, soil permeability soil structure,and soil tensile strength. Also,it provides the primary assessment of water quality parameters.From the foregoing findings, we concluded that SAR is strongly affected by the concentration of $\mathrm{Na}, \mathrm{Mg}$, and $\mathrm{Ca}$ ions in Tigris River water in both locations. The most variable parameter was $\mathrm{Mg}$ $(\mathrm{cv}=14.03 \%)$ and the least variable was $\mathrm{pH}(\mathrm{cv}=2.209 \%)$ in Suwaira region .Whereas, in Numaniyah region, the most variable parameter was $\mathrm{Ec}(\mathrm{cv}=32.868 \%$ )and the least variable was $\mathrm{pH}$ as well $(\mathrm{cv}=1.226 \%)$. The pattern of variability of water quality parameters is taking the form $\mathrm{Mg}>\mathrm{SAR}>\mathrm{Ec}>\mathrm{Ca}>\mathrm{Na}>\mathrm{pH}$ in Suwiara andNumaniyah regions respectively. The parameters of water quality were more variable in Suwaira region than Numaniyah region except Ec was more 
variable in Numaniyah region and was very highly variable.Most water quality parameters were of low variability $(\mathrm{cv}=<15 \%)$ except Ec parameter in Numaniyah region was the highly variable class $(\mathrm{cv}=>25 \%)$. SAR was significantly (negative) correlated with $\mathrm{Ca}$ ion and (positive ) correlated with $\mathrm{Na}$ and $\mathrm{Mg}$ ions in Suwaira region.But it shows significant (positive )correlation with $\mathrm{Na}$ and negative correlation with $\mathrm{Mg}$ in Numaniyah region. WQMs in both regions strongly reflected the interactions among the water quality, and SAR and Ec can be used to assess the quality of irrigation water. Also, the disposal of polluted and untreated or partially treated materials affected the water resources and reduced their quality potentially for agricultural uses in the study area of both regions .Models ( WQMs S2 and WQMs N2) were the best models for characterising the relations between $\mathrm{SAR}, \mathrm{Ec}, \mathrm{pH}$, and time scale.Accordingly, the continuous and periodic monitoring of water quality is highly recommended and it is critical to understand what management changes are necessary for long and short productivity schemes , particularly for crops that are sensitive to changes in water quality 
العـــــــد الخامس والعشرون

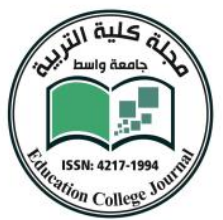

References

Basu, S. and K.S Lokesh, 2013.Spatial and temporal variations of river water quality :A case study of River Kabini at Nanjangud in Karnataka .InternationalJournal of Water Resources and Environmental Engineering :Vol.5 (10)pp.591-596.

Cannon ,MR, David A. Nimik, Thomas E. Cleasby, Stacy M. Kensey, and John H. Lambing (2004).Measured and Estimated Sodium-Adsorption Ratios for Tongue River and its Tributes ,Montana and Wyomingx .In US Dept. of Interior ,US Geologic survey ,Scientific Investigations report 2007-5072, Helen Publishing center http://int.water.usgs.gov./ .

Das,J and B.C. Acharya (2003).Hydrology and assessment of lotic water quality in Cutack city ,India ,Water, Air ,Soil pollution,150,163-175.

Datafit 9 soft ware.(2014).Version 9.1 .32 ,copyright C),Oakdale Engineering.

El-Sayed ,E. Omran( 2012).A proposed Model to assess and Map Irrigation Water well suitability using geospatial analysis.Water vol.4,545-567.

Gubta , P. , M. Vishwakarama ,P. M. Rawatani (2009). Assessment of water quality parameters of Kerwa Dam for drinking suitability ,International journal of theoretical and applied science ,1(2):53-55.

Hagras, M.A.(2013). WATER QUALITY ASSESSMENT AND HYDROCHEMICAL CHARACTERISTICS OF GROUNDWATER IN PUNJAB, PAKISTAN . IJRRAS 16 (2),pp254-262.

Ibrahim A., H. Juahir, M. E. Toriman, A. Mustaph, A. Azid and Hamza, A. Isiyaka,(2015). ASSESSMENT OF SURFACE WATER QUALITY USING MULTIVARIATE STATISTICAL TECHNIQUES IN THE TERENGGANU RIVER BASIN (Penilaian Kualiti Air Permukaan Menggunakan Teknik Statistik Multivariat bagi Lembangan Sungai Terengganu) Malaysian Journal of Analytical Sciences, Vol 19 No 2): $338-348$.

Malla,R., S. Shrestha ,S. K. Chapagain ,M. Shakya and T. Nakamura .(20015) physiochemical and Oxygen-Hydrogen Isotopic of Bagmati and Bishnomati Rivers and the shallow groundwater along the river corridors in Katmandu valley, Nepal . Journal of Water resources and Protection:7,1435-1448. 
Park,D.M. , S. A. White , Menchyk (2014).Assessing Irrigation water quality for pH, Salts, and Alkalinity .Journal for extension, vol.52,No.6.

Radwan,M. and A. El-Sadek(2008).Water quality assessment of irrigation and canals in Upper Egypt, Twelfth International Water Technology conference ,IWTC12,Alexanderia ,Egypt ,1239

Richards, L.A. et al(1954).Diagnosis and improvement of saline and alkali soils .Agriculture Handbook 60,US salinity laboratory, US Department of Agriculture, Riversides, California.

Sahoo, M. , M.R. Mahananda and P. Seth (2016).P physico-Chemical Analysis of surface and groundwater around Talcher Coal Field District Augul, Odisha ,India .Journal of geosciences and environment protection ,vol.4,26-37.

Sarala Thambavani, D. and Uma Mageswari T.S.R.( 2014).Modeling of Irrigation Network(MLBP_NN).International journal of chemical research CODEN(USA).Aug.Sep. Vol. 6 No 5 pp.3053-3061.

15-Sharma, V. and Y.K. Walia.(2015).water quality assessment using physio-chemical parameters and heavy metals of Gobind Sager Lake, Himacal Pradesh (India).

Singh,P. , A. K.Tiwari and P.K. Singh (2014).Hydro chemical characteristics and quality Assessment of groundwater of Ruchi Township Area ,Jharkhand ,India. Current world environment ;9(3).

Spss Software Program ,(2011). Version.20 IBM logo.ibm.com .

Wang,Q. ,Shebei Li ; Changjun Qi and F. Ding (2013).A review of surface. quality Models. The scientific world journal :No 1 pp 7. Wang,Q. ,Shebei Li ; Changjun Qi and F. Ding (2013).A Review of Surface Water quality Models. The scientific world journal :No 1 pp 7.

Xuan Yi; Rui Zou and H. Guo (2016).Global sensitivity analysis of the three dimensional nutrient e algae dynamic model for a large shallow lake .Ecological modeling 327(7484). 